\title{
Growth Response of Three Turfgrass Species to Nitrogen and Trinexapac-ethyl in Shade
}

\author{
D.S. Gardner ${ }^{1}$ \\ Dept. of Horticulture and Crop Science, 2021 Coffey Road, The Ohio State \\ University, Columbus, $\mathrm{OH} 43210-1086$
}

\author{
B.G. Wherley ${ }^{2}$ \\ Department of Crop and Soil Science, North Carolina State University, Raleigh, \\ NC 27695-7620
}

\section{Additional index words. Primo, tall fescue, sheep fescue, rough bluegrass}

\begin{abstract}
Previous research on the potential of the gibberellin inhibiting growth regulator trinexapac-ethyl(TE) [4-(cyclopropyl- $\alpha$-hydroxy-methylene)-3,5-dioxocyclohexanecarboxylic acid ethyl ester] to improve quality and density of shaded turfgrass has been conducted under neutral-density shade. However, some phytochrome-mediated growth responses of turfgrass, such as tillering, are different under deciduous shade versus neutral-density shade. The objectives of this study were to investigate 1) whether TE would result in improved stand density and quality of turfgrass grown under deciduous shade as has been observed under neutral-density shade and 2 ) the shade tolerance of sheep fescue (Festuca ovina $\mathbf{L}$. 'Quatro') compared to tall fescue (Festuca arundinacea Schreb. 'Plantation'), and rough bluegrass (Poa trivialis L.). Trinexapac-ethyl at either 0 or $29 \mathrm{~kg}^{\circ} \mathrm{ha}^{-1} \mathrm{a.i.} \mathrm{and} \mathrm{nitrogen} \mathrm{at} 12$ or $36 \mathrm{~kg} \cdot \mathrm{ha}^{-1}$ were applied on 23 May, 3 July, and 15 Aug. 2003 and 21 May 2004 to each species in a randomized complete block design under deciduous shade (about $9 \%$ of full sun). Clipping yield, color, and density data were collected for 6 weeks after the May applications in each year. Visual quality was assessed for 6 weeks after application in 2004 only. In 2003, TE significantly reduced clipping yields by $35 \%$ to $50 \%$ on sheep fescue, $58 \%$ to $76 \%$ on tall fescue and $55 \%$ to $80 \%$ on rough bluegrass. However, in 2004, yield reduction was $0 \%$ to $50 \%$ for all three species and there was no interaction between week, TE, and species. 'Plantation' tall fescue had the highest overall visual quality and density. Sheep fescue also provided an acceptable quality turf stand. TE application did not significantly impact the quality of these species. Rough bluegrass performance was unacceptable, and high rate applications of TE to this species in shade resulted in significant $(P<0.05)$ losses in density. Trinexapac-ethyl application, based on the results of this study, may not enhance turf quality of cool season grasses grown under dense tree shade.
\end{abstract}

Deciduous tree canopies alter the spectral composition, or red to far-red ( $\mathrm{R}$ to $\mathrm{FR}$ ) ratio, and photosynthetic photon flux (PPF) of solar radiation available to plants in shade (Bell et al., 2000; Shirley, 1945). The R to FR ratio is the ratio of the photon flux of light in the 10$\mathrm{nm}$ band around $660 \mathrm{~nm}$ (red light) to light in the $10-\mathrm{nm}$ band around $730 \mathrm{~nm}$ (far-red light). Low PPF results in lower plant carbohydrate levels, reduced tillering and stand density, and altered leaf size and structure. Reduced R to FR ratios lead to decreased tillering, leafblade width and thickness, and chlorophyll contents (Dudeck and Peacock, 1992; Wherley et al., 2005). Cool-season turfgrass species, such as kentucky bluegrass (Poa pratensis L.) and perennial ryegrass (Lolium perenne L.) are not well adapted to growth in a shaded environment and exhibit more upright growth

\footnotetext{
Received for publication 24 Feb. 2005. Accepted for publication 14 may 2005. Salaries and research support provided in part by State and Federal funds appropriated to the Ohio Agricultural Research and Development Center, The Ohio State University. Journal article HCS 05-02.

${ }^{1}$ Assistant professor. To whom requests for reprints should be addressed; e-mail gardner.254@osu.edu. ${ }^{2}$ Graduate student.
}

to 5 weeks, treated turfgrass may grow faster than the untreated control (Lickfeldt et al., 2001). Application of TE caused increased tiller density on seedling perennial ryegrass (Ervin and Koski, 1998). Other potential benefits derived from TE are darker color and improved stress tolerance (Fagerness and Penner, 1998; Lickfeldt et al., 2001)

Several studies have investigated the use of TE to enhance shade tolerance of turfgrass. However, these studies were conducted under neutral density shade, using artificial shade structures that lowered PPF, but did not affect $\mathrm{R}$ to FR (Bell et al., 2000). Shade tolerance of some species has been enhanced by repeated TE use (Ervin et al., 2002; Goss et al., 2002; Steinke and Stier, 2003). Qian et al. (1998) reported increases in zoysiagrass (Zoysia japonica Steud.) rhizome mass following TE applications in dense shade. However, the post-suppression growth surge following TE use can cause a reduction in carbohydrate reserves relative to the untreated control (Han et al., 1998; Qian and Engelke, 1999).

Some phytochrome-mediated growth responses of turfgrass, such as leaf width, leaf thickness, and tillering, are different under neutral-density shade compared to tree shade (Wherley et al., 2005). Furthermore, recent research suggests that the response of plants to low R to FR of deciduous shade does not directly involve GA biosynthesis (Zheng et al., 2001). A significant amount of shade research has underestimated the extent and array of developmental responses to foliage shade (Buisson and Lee, 1993). Therefore, whether turf under deciduous shade responds similarly to TE compared to turf under neutral-density shade is unclear.

In the present study, the interactive effects of TE and nitrogen were studied on three shade tolerant species (Christians, 2004). The objectives of this study were to investigate 1) whether TE would delay seasonal decline of turfgrass under deciduous shade and result in improved stand density and quality, as has been observed under neutral-density shade and 2) the shade tolerance of sheep fescue compared to tall fescue and rough bluegrass.

\section{Materials and Methods}

the general consensus is that among the coolseason grasses, the fine fescues have superior shade tolerance (Christians, 2004). Sheep fescue (Festuca ovina L.) is a fine fescue that has in recent years received more attention as a species for use as a turfgrass. It can be utilized in the same management situations as the other fine fescues. 'Quatro' is the only cultivar of sheep fescue currently marketed for use as a turfgrass (Christians, 2004).

Trinexapac-ethyl (TE, Primo, Syngenta Crop Protection, Greensboro, NC) is a PGR that reduces gibberellic acid(GA) synthesis by inhibiting the hydroxylation of the $3 \beta$-position on the ent-gibberellene skeleton, a step that is required for biological activity (Adams et al., 1992). Application of TE significantly suppresses turfgrass growth for 4 to 5 weeks under normal field conditions (Daniels and Sugden, 1996; Fagerness and Yelverton, 2000). After 4
The study was initiated on 15 June 2002 at the Ohio Turfgrass Foundation Research and Education Facility, Columbus, Ohio. Plots were constructed by excavating to a $30 \mathrm{~cm}$ root zone depth and backfilling with a $90 \%$ sand and $10 \%$ peat $(\mathrm{v} / \mathrm{v})$ mixture overtop an existing native clay loam soil.

Three species, 'Plantation'tall Fescue(Pennington Seed, Madison, Ga.), rough bluegrass (variety unstated, Earnst Seed, Medville, Pa.) and 'Quatro' sheep fescue (Earnst Seed, Medville, $\mathrm{Pa}$.) were established by seed on 28 June 2002 at rates of $33.5,9.6$, and $33.5 \mathrm{~g} \cdot \mathrm{m}^{-2}$, respectively. Each plot was $2.4 \mathrm{~m}^{2}$ and plots were arranged in a randomized complete block design with three rows of four plots per block to support a 3 species $\times 2$ nitrogen rate $\times 2$ TE rate factorial. The three blocks were arranged from east to west and placed in the center of a 9-m 
area that lies between, and under the canopy of, a single row of mature trees (primarily Acer saccharinum and Platanus occidentalis that were 20 to $25 \mathrm{~m}$ in height) and a grove of mature woods. Shade level across the area of the study was uniform throughout the day and shade variability within individual plots exceeded the shade variability between plots within a replication. However, shade density was generally higher in the first replication, due to two additional trees placed between the tree hedge and the research plots. Blocking was across this shade variability.

Photosynthetic photon flux was measured continuously from 15 June 2002 through 31 June 2004. A cosine corrected PAR light sensor (Spectrum Technologies, Plainfield, Ill.) was mounted to a pole $30 \mathrm{~cm}$ above the soil surface and positioned adjacent to the plot and also in full sun near the study area. PPF was measured every $15 \mathrm{~min}$ and the cumulative data stored using a Spectrum Technology data logger and average daily total PPF $\left(\mathrm{mol} \cdot \mathrm{m}^{-2} \cdot \mathrm{d}^{-1}\right)$ was determined using Specware software (Spectrum Technologies).

An $18 \mathrm{~N}-1.3 \mathrm{P}-14.9 \mathrm{~K}$ granular fertilizer (United Horticultural Supply, Maumee, Ohio) was applied at $24 \mathrm{~kg} \mathrm{~N} /$ ha monthly from June through October (excluding July) during 2002 and irrigation was provided as necessary to ensure good stand establishment. Supplemental irrigation was provided in 2003 and 2004 in order to provide adequate moisture for turfgrass growth. However, a large rainfall $(11.25 \mathrm{~cm})$ occurred 4 WAT in 2004 which caused much higher soil moisture levels on the plots for 1 week. Beginning when seedlings attained a height of $9.8 \mathrm{~cm}$ and for the duration of the study, plots were mowed as needed with a rotary push mower to a height of $7.6 \mathrm{~cm}$ and the clippings collected.

Trinexapac-ethyl (Primo 1EC; Syngenta Crop Protection, Greensboro, N.C.) was applied on 23 May, 3 July, and 15 Aug. 2003 and 21 May 2004 using a $\mathrm{CO}_{2}$-powered backpack sprayer equipped with 8002 flat fan nozzles (Tee Jet Inc., Minneapolis, Minn.) calibrated to deliver either 0 or $0.29 \mathrm{~kg} \cdot \mathrm{ha}^{-1}$ a.i. TE in $815 \mathrm{~L}$ of $\mathrm{H}_{2} \mathrm{O} /$ ha. Nitrogen ('Signature greens grade' $18 \mathrm{~N}-1.3 \mathrm{P}-14.9 \mathrm{~K}, \mathrm{UHS} /$ Verdicon, Columbus, Ohio) was applied at 12 or $36 \mathrm{~kg} \mathrm{~N} / \mathrm{ha}$ on 23 May, 3 July, and 15 Aug. 2003 and 21 May $20046 \mathrm{~h}$ after TE application using a shaker can and irrigated in with $0.5 \mathrm{~cm}$ water. The label states that TE is rainfast within $1 \mathrm{~h}$.

The plots were mowed weekly at $7.6 \mathrm{~cm}$. Clippings were collected for 6 weeks following the 23 May 2003 and 21 May 2004 applications of TE and fertilizer, dried in a forced air oven at $60{ }^{\circ} \mathrm{C}$ for $48 \mathrm{~h}$, and weighed. Data were not collected after the first application cycle of TE and nitrogen in either year because turfgrass growth had declined so that TE would not appreciably decrease clipping yields. Estimates of turfgrass density and color were made at 2-week intervals for 6 weeks after initial fertilizer and TE application in both 2003 and 2004. Estimates of turfgrass visual quality were made each week for 6 weeks after fertilizer and TE application in 2004 only. Turfgrass visual quality was evaluated on a scale of 1-9 where 1 = poorest quality, 6 = lowest acceptable quality, and $9=$ best quality. Density was rated on a scale of 1 to 9 where $1=$ bare soil, $6=$ lowest acceptable density, and $9=$ highest density. Color was rated on a scale of 1 to 3 where $1=$ lightest green and $3=$ darkest green color. The data were analyzed using the general linear models (GLM) procedure of SAS (SAS Institute, 1990). Data were analyzed as a randomized complete block design with repeated measures. Year $\times$ treatment effect interactions were significant. Therefore, years were analyzed separately. Fisher's protected least significant difference (LSD) test was used to compare means.

\section{Results}

Light environment. The average PPF on the plots during the two study periods was equivalent to $9 \%$ of full sun. The R to FR ratio of the plots was measured in June and September 2003 and was $0.428 \pm 0.065$ on the shaded plots compared to $1.165 \pm 0.026$ in full sun next to the plots.

Clipping yields. Trinexapac-ethyl reduced clipping yields of all three species in both 2003 and 2004 (Table 1). There were no differences in clipping yield response between species in 2003. However, in 2004, sheep fescue had higher clipping yields than either tall fescue or rough bluegrass (Fig. 1, Table 1). No differences in yield response were detected due to nitrogen application rate in either year.

There was an interaction between species and TE in 2003 but not in 2004. Analysis of variance also indicated an interactive effect between week and TE application in both 2003 and 2004, and between week, TE, and species in 2003 (Fig. 1). During the 6-week study in 2003, TE application reduced clipping yields by $35 \%$ to $50 \%$ on sheep fescue, $58 \%$ to $76 \%$ on tall fescue and $55 \%$ to $80 \%$ on rough bluegrass. However, in 2004, the yield reduction was $0 \%$ to $50 \%$ for all three species and no interaction between week, TE, and species was observed.

An interaction between week, nitrogen and TE was observed in 2003. In weeks 1 to 4, clipping yields were slightly higher on plots that received no TE and higher nitrogen, compared to plots that received no TE and lower nitrogen (data not shown). These differences were not observed in weeks 5 and 6 or between TE treated plots. None of the differences between weeks was significant, and this interaction was not observed in 2004.

Density, color, and visual quality. Stand density rating differences between species were observed in 2003 and there was an interaction between week and species in 2003 and 2004 (Table 1). Overall stand density ratings for weeks 1 to 6 in 2003 were 7.5, 7.2, and 6.2 for rough bluegrass, tall fescue, and sheep fescue, respectively. Fisher's LSD indicated that sheep fescue plots were significantly less dense than tall fescue and rough bluegrass. In 2004, overall stand density ratings for weeks 1 to 6 were 6.3 , 6.3 , and 5.8 for rough bluegrass, tall fescue, and sheep fescue, respectively, and the differences

Table 1. Analysis of variance table for turfgrass species, $\mathrm{N}$ application rate, and trinexapac-ethyl effects on clipping yields and visual quality of turfgrass stands maintained in shade.

\begin{tabular}{|c|c|c|c|c|c|c|c|}
\hline & \multicolumn{7}{|c|}{$P$ values } \\
\hline & \multicolumn{3}{|c|}{2003} & \multicolumn{4}{|c|}{2004} \\
\hline & Yield & Density & Color & Yield & Density & Color & Quality \\
\hline Replication (R) & $* * *$ & $* *$ & NS & $* *$ & $* *$ & NS & NS \\
\hline Species (S) & NS & $* * *$ & $* * *$ & $* * *$ & NS & $* * *$ & $* *$ \\
\hline $\mathrm{N}$ rate $(\mathrm{N})$ & NS & NS & NS & NS & NS & NS & NS \\
\hline Trinexapac-ethyl (T) & $* * *$ & NS & $* * *$ & $* * *$ & NS & $*$ & $* *$ \\
\hline $\mathrm{S} \times \mathrm{N}$ & NS & NS & $* *$ & NS & NS & NS & NS \\
\hline $\mathrm{S} \times \mathrm{T}$ & $*$ & NS & NS & NS & $*$ & $* *$ & $* *$ \\
\hline $\mathrm{N} \times \mathrm{T}$ & NS & NS & NS & NS & NS & NS & NS \\
\hline $\mathrm{S} \times \mathrm{N} \times \mathrm{T}$ & NS & NS & NS & NS & NS & NS & NS \\
\hline \multicolumn{8}{|c|}{$\mathrm{R} \times \mathrm{S} \times \mathrm{N} \times \mathrm{T}($ Error $\mathrm{A})$} \\
\hline Week (W) & $* * *$ & $* * *$ & NS & $* * *$ & $* * *$ & NS & $* * *$ \\
\hline $\mathrm{W} \times \mathrm{R}$ & $* * *$ & NS & $*$ & $* * *$ & $* *$ & NS & $* *$ \\
\hline $\mathrm{W} \times \mathrm{S}$ & $* * *$ & $* * *$ & NS & $* * *$ & $* *$ & NS & $* * *$ \\
\hline $\mathrm{W} \times \mathrm{N}$ & $* *$ & NS & NS & NS & NS & NS & NS \\
\hline $\mathrm{W} \times \mathrm{T}$ & $* * *$ & NS & NS & $* * *$ & NS & $*$ & $* *$ \\
\hline $\mathrm{W} \times \mathrm{S} \times \mathrm{N}$ & NS & NS & NS & NS & NS & NS & NS \\
\hline $\mathrm{W} \times \mathrm{S} \times \mathrm{T}$ & $* * *$ & NS & $*$ & NS & NS & NS & NS \\
\hline $\mathrm{W} \times \mathrm{N} \times \mathrm{T}$ & $* *$ & NS & NS & NS & NS & NS & NS \\
\hline $\mathrm{W} \times \mathrm{S} \times \mathrm{N} \times \mathrm{T}$ & NS & NS & NS & NS & NS & NS & NS \\
\hline
\end{tabular}

$\overline{\mathrm{NS}, *, * * * * * *}$ Nonsignificant or significant at $P=0.05,0.01$, or 0.001 , respectively. 
were not significant. Stand density decreased over time in both years of the study (Table 2). Density of tall fescue and rough bluegrass was significantly higher than that of sheep fescue in 2003. However, density or rough bluegrass was significantly lower than that of tall fescue or sheep fescue in 2004 (Table 2).

Nitrogen had no effect on stand density ratings in either 2003 or 2004. TE application had no effect on stand density in 2003. But, there was an interaction between species and TE observed in 2004. TE application increased
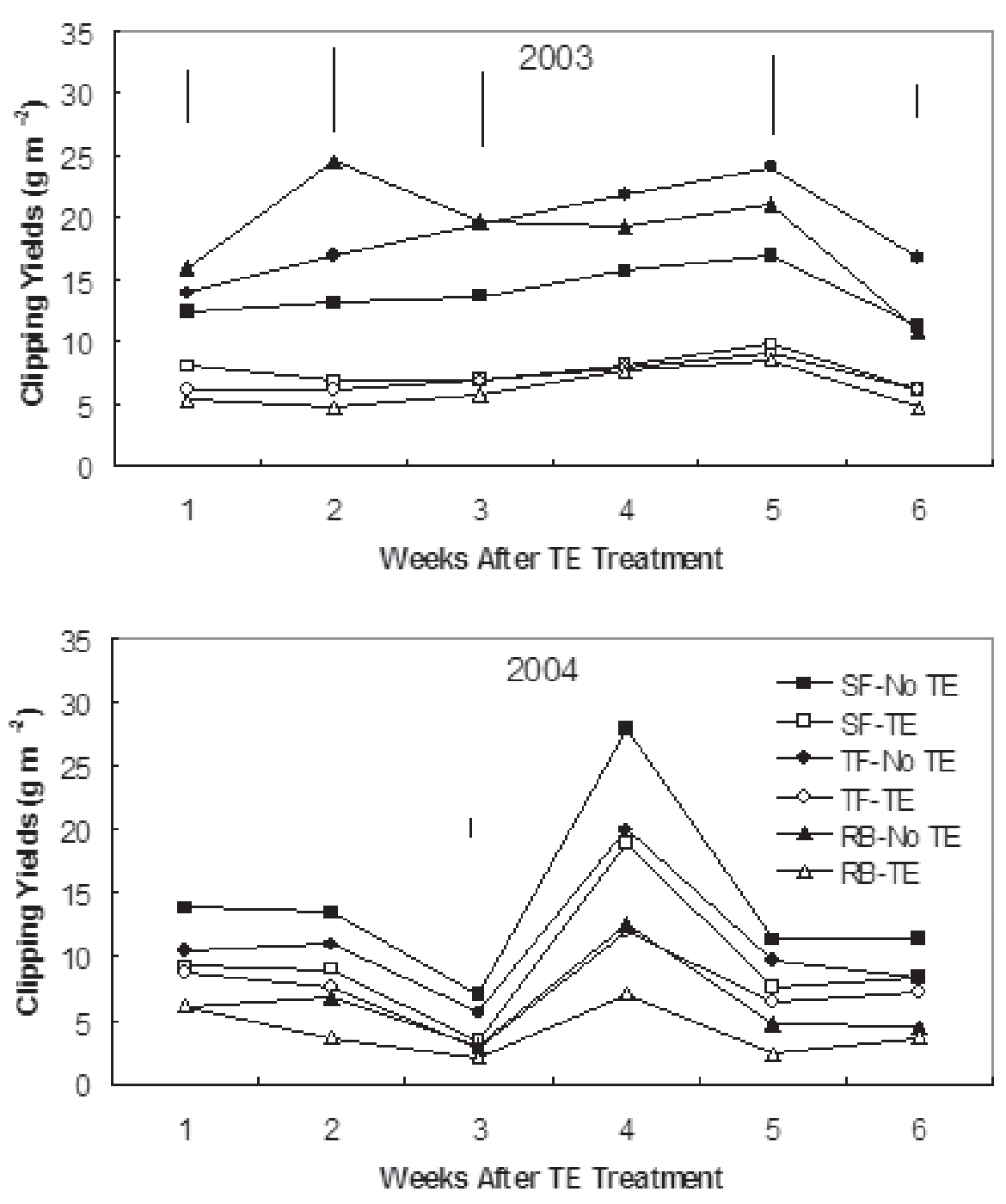

Fig. 1. Change in clipping yield production over 6 weeks after application of ethyl-ethyl (TE) compared to no growth regulator (No TE) on sheeps fescue (SF), tall fescue (TF) or rough bluegrass (RB) maintained under $90 \%$ deciduous shade in 2003 and 2004 at Columbus, Ohio. Fisher's protected LSD $(P=0.05)$ for comparing species and TE application combinations at each week are indicated by error bars.

Table 2. Change in stand density of three turfgrass species managed in shade over time during 2003 and 2004. Means are pooled over TE and nitrogen treatments.

\begin{tabular}{|c|c|c|c|c|c|c|}
\hline \multirow[b]{4}{*}{ Species } & \multicolumn{6}{|c|}{ Turfgrass stand density $\left(1-9^{2}\right)$} \\
\hline & \multicolumn{3}{|c|}{2003} & \multicolumn{3}{|c|}{2004} \\
\hline & \multicolumn{6}{|c|}{ Weeks after TE treatment } \\
\hline & 2 & 4 & 6 & 2 & 4 & 6 \\
\hline Sheep fescue & $6.6 \mathrm{~b}$ & $6.7 \mathrm{~b}$ & $5.5 \mathrm{~b}$ & 6.4 & $6.1 \mathrm{a}$ & $6.3 \mathrm{a}$ \\
\hline Tall fescue & $7.1 \mathrm{~b}$ & $7.3 \mathrm{a}$ & $7.3 \mathrm{a}$ & 6.6 & $5.8 \mathrm{ab}$ & $6.4 \mathrm{a}$ \\
\hline Rough bluegrass & $7.8 \mathrm{a}$ & $7.8 \mathrm{a}$ & $7.0 \mathrm{a}$ & 6.7 & $5.3 \mathrm{~b}$ & $5.5 \mathrm{~b}$ \\
\hline $\operatorname{LSD}(\alpha=0.05)^{\mathrm{y}}$ & 0.5 & 0.5 & 0.4 & NS & 0.7 & 0.6 \\
\hline
\end{tabular}

${ }^{2}$ Density was evaluated visually on a scale of $1=$ bare soil, $6=$ minimum acceptable density, and $9=$ most dense.

${ }^{y}$ According to Fishers protected LSD. Values are for comparing turf species within weeks. ferences in color were observed on sheep fescue or tall fescue and rough bluegrass color was significantly lower due to TE application.

Visual quality ratings were taken in 2004 only. There was an interaction between species and TE rate. Sheep fescue and tall fescue visual quality was not affected by TE application. However, TE application reduced visual quality of rough bluegrass from 7 (untreated) to 5 (treated) based on a 1 to 9 scale. There was an interaction between week and TE application and also between week and species (Fig. 2). Trinexapac-ethyl application significantly reduced the mean visual quality of the three species 4 to 6 weeks after application. The reduction in visual quality was greater on rough bluegrass than on sheep fescue or tall fescue.

\section{Discussion}

Several studies have investigated the use of TE as a management tool on shaded turfgrass. However, most of these studies were conducted using neutral-density shade structures (Ervin et al., 2002; Goss et al., 2002; Steinke and Stier, 2003; Stier and Rogers, 2001). The advantage of neutral-density structures is uniformity of shading. However, a considerable amount of turfgrass growth and development in shade is controlled by phytochrome and growth responses are different under deciduous versus neutral-density shade (Wherley et al., 2005). The decrease in light quality that is perceived by the phytochrome system of the plant has resulted in significant efforts to understand both the role of phytochrome in plant growth and development, and to develop methods of better duplicating foliage shade (Lee, 1985). Recent research suggests that the effects of low R to FR in deciduous shade are probably not mediated by GA (Metzger and Dusabek, 1991; Wherley et al., 2005; Zheng et al, 2001). Those findings, together with the results of the present study, indicate that TE use may not improve shade tolerance of tall fescue, sheep fescue, or rough bluegrass grown under deciduous shade.

Most previous studies have used a 4-week interval to prevent a rebound effect. Ervin et al. (2004) improved quality of creeping bentgrass (Agrostis stolonifera) under $88 \%$ shade by applying TE every 2 weeks. A6-week application interval was utilized in this study. Our purpose was to determine if TE applied at a higher rate less frequently could improve stand density in lower maintenance situations, such as home lawns or golf course roughs. Previous research suggests that total nonstructural carbohydrates in the plant are more affected by application rate than by application timing (Han et al., 1998). Metabolism of TE by shaded turfgrass may occur at a different rate than in full sun, and this would also influence recommended rates and timings. However, no research on metabolism rate of TE in shaded turfgrass compared to turfgrass in full sun has been conducted. A rebound has been observed on turfgrass 7 weeks after TE application (Ervin and $\mathrm{Ok}, 2001)$. Therefore, it is possible that decreases in stand density observed in this 
Table 3. Effect of TE application on color of three turfgrass species grown in shade. Color rating was a subjective visual evaluation ( 1 = light green, 3 = darkest green $)$.

\begin{tabular}{|c|c|c|c|c|c|c|}
\hline \multirow{3}{*}{$\begin{array}{l}\text { TE rate } \\
\left(\mathrm{kg} \cdot \mathrm{ha}^{-1} \text { a.i. }\right)\end{array}$} & \multicolumn{6}{|c|}{ Species } \\
\hline & \multicolumn{3}{|c|}{2003} & \multicolumn{3}{|c|}{2004} \\
\hline & SF & $\mathrm{TF}$ & $\mathrm{RB}$ & $\mathrm{SF}$ & $\mathrm{TF}$ & $\mathrm{RB}$ \\
\hline 0 & $1.1 \mathrm{e}$ & $1.9 \mathrm{c}$ & $1.4 \mathrm{~d}$ & $2.1 \mathrm{~b}$ & $2.8 \mathrm{a}$ & $2.1 \mathrm{~b}$ \\
\hline 0.29 & $1.9 \mathrm{c}$ & $2.8 \mathrm{a}$ & $2.6 \mathrm{~b}$ & $2.1 \mathrm{~b}$ & $2.9 \mathrm{a}$ & $1.3 \mathrm{c}$ \\
\hline $\operatorname{LSD}(\alpha=0.05)^{\mathrm{z}}$ & & 0.2 & & & 0.3 & \\
\hline
\end{tabular}

${ }^{\mathrm{z}}$ According to Fishers protected LSD. Values are for comparing color within or between species.

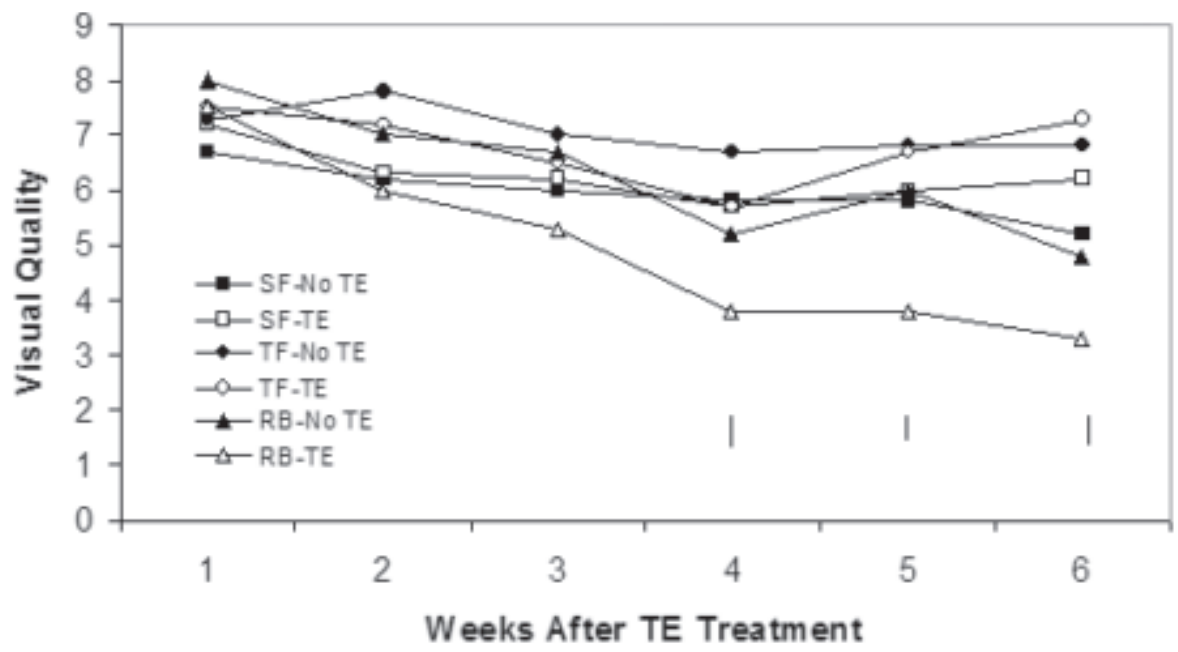

Fig. 2. Change in visual quality over 6 weeks after application of ethyl-ethyl (TE) compared to no growth regulator (No TE) on sheeps fescue (SF), tall fescue (TF) or rough bluegrass (RB) maintained under $90 \%$ deciduous shade in 2003 and 2004 at Columbus, Ohio. Fisher's protected LSD $(P=0.05)$ for comparing species and TE application combinations at each week are indicated by error bars.

study were due to thinning caused by postsuppression rebound.

In the first year of this study, the use of TE resulted in considerable decreases in clipping yields that were significant in 5 of the 6 weeks of the study (Fig. 1). There was also a significant increase in turf color (darker green) due to TE application (Table 3). However, during this first study, the density of the sheep fescue and rough bluegrass declined, independent of nitrogen or TE application rate (Table 2). However, tall fescue density remained unchanged.

In year 2 of the study, several rain events totaling $11.25 \mathrm{~cm}$ between the week 3 and 4 clipping collections dates most likely caused the growth spike observed at 4 WAT. However, the use of TE resulted in significant clipping yield reductions only in week 3 (Fig. 1). Unlike the first year of the study, the use of TE did not improve color or density of sheep fescue or tall fescue, and significantly decreased color and density of rough bluegrass (Tables 2 and 3 ). The decrease in color and density of rough bluegrass contributed to its overall lower visual quality in weeks 4,5 , and 6 of the 2004 study, compared to the fescues (Fig. 2). Although Stienke and Stier (2003) used TE safely on Poa supina, a related species, there is no labeled rate for TE on rough bluegrass. In our study we used the tall fescue rate for consistency in the trial. This relatively high rate may have resulted in phytotoxicity on the rough bluegrass, leading to the decrease in overall visual quality.

Ervin et al. (2002) reported that TE application to zoysiagrass improved stand density in $77 \%$ shade, but not in $89 \%$ shade. Similarly,
Goss et al. (2002) reported increased turf cover due to TE application under $80 \%$ shade. In the present study under $91 \%$ shade, TE application did not result in improved stand density, in agreement with Ervin et al. (2002). Wherley et al. (2005) reported decreased tillering of tall fescue under deciduous shade, compared to neutral-density shade. Therefore, we speculate, based on previous research and the results of the present study, that TE applied on a 6-week interval will not help to delay thinning in turfgrass under moderate or deep tree shade.

Three applications totaling 36 or $108 \mathrm{~kg} / \mathrm{N}$ ha were applied per season during the study. These rates are much lower than what has been studied on kentucky bluegrass (Ervin and Koski, 2001). We applied at lower rates to see if reduced nitrogen would also result in improved stand density by reducing excessive growth following fertilization. However, few differences were seen in this study due to nitrogen application. It is possible that the difference in our application rates was too small to cause an effect under the conditions of the study.

Three turfgrass species were utilized in this study. 'Plantation' tall fescue was selected based on its performance in trials under similarly shaded conditions (Gardner and Taylor, top performer based on overall visual quality and density, providing an acceptable quality (6 to 7 on a 1 to 9 scale) stand. Based on our results, 'Quatro'sheeps fescue will also provide an acceptable quality turf stand under moderate to dense shade conditions. Infrequent TE application did not significantly impact the overall 2002). At the end of present study, it was the quality of these species. The performance of the rough bluegrass tested was generally unacceptable. Future studies need to be conducted to identify an acceptable shade and full sun rate for TE use on rough bluegrass. Future research should address the metabolism rate of TE in shaded turfgrass to more accurately determine a proper application schedule. Trinexapac-ethyl application, based on the results of this study, may not enhance turf quality of cool season grasses grown under dense tree shade.

\section{Literature Cited}

Adams, R., E. Kerber, K. Pfister, and E.W. Weiler. 1992. Studies on the action of the new growth retardent CGA163935 (Primo), p. 818-827. In: C.M. Karssen et al. (eds.). Progress in plant growth regulation. Kluwer, Dordrecht, the Netherlands.

Beard, J.B. 1973. Turfgrass: Science and culture. Prentice-Hall Inc., Englewood Cliffs, N.J.

Bell G.E., T.K. Danneberger, and M.J. McMahon. 2000. Spectral irradiance available for turfgrass growth in sun and shade. Crop Sci. 40:189-195

Buisson, D. and D. W. Lee. 1993. The developmental response of papaya leaves to simulated canopy shade. Am. J. Bot. 80:947-952.

Christians, N. 2004. Fundamentals of turfgrass management. Ann Arbor Press, Chelsea, MI. p. 33-58.

Daniels, R.W. and S.K. Sugden, 1996. Opportunities for growth regulation of amenity grass. Pestic. Sci. 47:363-369.

Dudeck A.E. and C.H. Peacock C.H. 1992. Shade and turfgrass culture, p. 269-284. In: D.V. Waddington, R.N. Carrow, and R.C. Shearman (eds.). Turfgrass. ASA-CSSA-SSSA Monogr. 32.

Ervin, E.H., X. Zhang, S.D. Askew, and J.M. Goatley, Jr. 2004. Trinexapac-ethyl, propiconazole, iron, and biostimulant effects on shaded creeping bentgrass. HortTechnoogy 14(4):500-506.

Ervin, E.H., C.H. Ok, B.S. Fresenberg, and J.H. Dunn. 2002. Trinexapac-ethyl restricts shoot growth and prolongs stand density of 'Meyer' zoysiagrass fairway under shade. HortScience 37:502-505.

Ervin, E.H. and A.J. Koski. 2001. Kentucky bluegrass responses to trinexapac-ethyl, traffic, and nitrogen. Crop Sci. 41:1871-1877.

Ervin, E.H. and C.H. Ok. 2001. Influence of plant growth regulators on suppression and quality of 'Meyer' zoysiagrass. J. Env. Hort. 19(2):57-60.

Ervin, E.H., and A.J. Koski. 1998. Growth responses of Lolium perenne L. to trinexapac-ethyl. HortScience 33:1200-1202.

Fagerness, M.J. and D. Penner. 1998. Evaluation of V-10029 and trinexapac-ethyl for annual bluegrass seedhead suppression and growth inhibition in five cool-season species. Weed Technol. 12:436-440.

Fagerness, M.J. and F.H. Yelverton. 2000. Tissue production and quality of 'Tifway'bermudagrass as affected by seasonal application patterns of trinexapac-ethyl. Crop Sci. 40:493-497.

Gardner, D.S. and J.A. Taylor. 2002. Change over time in quality and cover of various turfgrass species and cultivars maintained in shade. HortTechnology 12(3):465-469.

Goss, R.M., J.H. Baird, S.L. Kelm, and R.N. Calhoun. 2002. Trinexapac-ethyl and nitrogen effects on creeping bentgrass grown under reduced light conditions. Crop Sci. 42:472-479.

Han, S.W., T.W. Fermanian, J.A. Juvik, and L.A. Spomer. 1998. Growth retardant effects on visual 
quality and nonstructural carbohydrates of creeping bentgrass. HortScience 33:1197-1199.

Lickfeldt, D.W., D.S. Gardner, B.E. Branham, and T.B. Voigt. 2001. Implications of repeated trinexapac-ethyl applications on kentucky bluegrass. Agron J. 93:1164-1168.

Metzger, J.D, and K Dusabek. 1991. Determination of the cellular mechanisms regulating thermoinduced stem growth in Thlaspi arvense L. Plant Physiol. 97:630-637.

Qian, Y.L. and M.C. Engleke. 1999. Influence of trinexapac-ethyl on Diamond zoysiagrass in a shade environment. Crop Sci. 39:202-208.

Qian, Y.L., M.C. Engleke, M.J.V. Foster, and
S. Reynolds. 1998. Trinexapac-ethyl restricts shoot growth and improves quality of 'Diamond' zoysiagrass under shade. HortSci. 33:1019-1022.

SAS Institute, 1990. SAS user's guide: Statistics. 4th ed. SAS Inst., Cary, N.C.

Shirley L.H. 1945. Light as an ecological factor and its measurement. Bot. Rev. 11:463-524.

Steinke, K. and J.C. Stier. 2003. Nitrogen selection and growth regulator applications for improving shaded turf performance. Crop Sci. 43:1399-1406.

Stier, J.C. and J.N. Rogers, III. 2001. Trinexapacethyl and iron effects on supine and Kentucky bluegrass under low irridance. Crop Sci. 41:457-465.

Tisdale, S. L., W.L. Nelson, J.D. Beaton, J.H. Havlin. 1993. Soil fertility and fertilizers. MacMillan Publ. Co., New York.

Wherley, B.E., D.S. Gardner, and J.D. Metzger. 2005. Tall fescue photomorphogenesis as influenced by changes in the spectral composition and light intensity. Crop Sci. (in press).

Zheng, Z.L., Z. Yang, J.C. Jang, and J.D. Metzger. 2001. Modification of plant architecture in chrysanthemum by ectopic expression of the tobacco phytochrome $B 1$ gene. J. Amer. Soc. Hort. Sci. 126(1):19-26. 